\title{
Preservation of armoured scale insects on angiosperm leaves from the Eocene of Germany
}

Torsten Wappler and Yair Ben-Dov

Acta Palaeontologica Polonica 53 (4), 2008: 627-634 doi:http://dx.doi.org/10.4202/app.2008.0407

Of the 30 extant orders of insects, scale insects (Hemiptera: Coccoidea) have one of the best fossil records among insects that probably extends to the early Mesozoic. Most fossil Coccoidea records are of adult males which have been trapped in amber, whereas adult females are less common, probably because of their sedentary occurrence on plants. Descriptions, photos, and SEM micrographs are presented of over 250 well-preserved scale covers of adult females and nymphal stages of armoured scale insects (Hemiptera: Coccoidea: Diaspididae) which were found on dicotyledonous and monocotyledonous fossil leaves in Middle Eocene deposits from Germany. The structure of these fossil scale covers closely agrees with that of extant Diaspididae. These armoured scale insects belong to the subfamily Aspidiotinae. The age of this insect-plant association-47 to 44 million-year-old-indicates that the Diaspididae have a long history in the Palaearctic region.

Key words: Insecta, Hemiptera, Coccoidea, Diaspididae, plant-insect interactions, herbivory, parthenogenesis, Eocene, Messel, Eckfeld, Germany.

Torsten Wappler [twappler@uni-bonn.de] Steinmann-Institut für Geologie, Mineralogie, Paläontologie, Bereich Paläontologie, Universität Bonn, Nussallee 8, D-53115 Bonn, Germany; Yair Ben-Dov [yairbd@netvision.net.il] Department of Entomology, Agricultural Research Organization, The Volcani Center, P.O. Box 6, Bet Dagan 50250, Israel.

This is an open-access article distributed under the terms of the Creative Commons Attribution License (for details please see creativecommons.org), which permits unrestricted use, distribution, and reproduction in any medium, provided the original author and source are credited. 
Fari) Full text $(459.4 \mathrm{kB})$ ।

Far 5 Supplementary file $(506.8 \mathrm{kB})$ 